\title{
Illkögretim 6., 7. ve 8. Sinuf Fen ve Teknoloji Dersi Yapılandırmacı Öğrenme Ortamlarının Değerlendirilmesi
}

\author{
Nevzat YİĞİT \\ Karadeniz Teknik Üniversitesi Fatih Eğitim Fakültesi İlköğretim Bölümü \\ E-mail:nyigit@ktu.edu.tr
}

Muhammet Mustafa ALPASLAN

Muğla Sitkı Koçman Üniversitesi Eğitim Fakültesi Ortaöğretim Fen ve Matematik Alanlar Bölümü

E-mail:mustafaalpaslan@mu.edu.tr

Yasin CINEMRE

Karadeniz Teknik Üniversitesi Eğitim Bilimleri Enstitüsü Illköğretim Anabilim Dalı

E-mail: yasincinemre@hotmail.com

Bilal BALÇIN

Karadeniz Teknik Üniversitesi Ĕ̆itim Bilimleri Enstitüsü İlköğretim Anabilim Dalı E-mail: bilalbalcin@hotmail.com

$\ddot{O}_{z e t}$

Bu araştırmada, ilköğretim II. kademe öğrencilerinin fen ve teknoloji dersine yönelik yapılandırmacı öğrenme ortamı hakkında görüşleri belirlenmeye çalışılmıştır. Bu çerçevede, öğrencilerin yapılandırmacı öğrenme ortamı hakkında görüşleri ile sınıf düzeyleri ve cinsiyetleri arasındaki ilişkkinin varlı̆̆ araştırılmıştır. Araşstırma, Trabzon İl'inde öğrenim gören ve rastgele seçilen 1882 ilköğretim II. kademe ögrrencisine uygulanmıştır. Araşstırma hipotezlerini test etmek amaciyla MANOVA ve tek yönlü ANOVA testleri kullanılmıştır. Veri analizi sonucuna göre, ilköğretim II. kademe öğrencilerinin fen ve teknoloji dersi yapılandırmacı öğrenme ortamlarının değerlendirilmesi hususunda genel olarak cinsiyete ve sinıf düzeyine göre anlaml düzeyde farklllk gösterdikleri tespit edilmiştir. Bu sonuçlar doğrultusunda; ilköğretim II. kademe öğrencilerinin fen ve teknoloji dersindeki yapılandırmacı öğrenme ortamların etkileyen faktörlerin tespit edilerek yapılandırmacı öğrenme ortamların artıracak çalışmaların yapılmasl; erkek öğrencilerin fen ve teknoloji dersindeki yapılandırmacı öğrenme ortamına iliş̧kin sahip oldukları algılarının tespit edilmesi ve yapılandırmacı ögrenme ortamlarını arttıracak çalışmaların yapılması önerilmektedir.

Anahtar Kelimeler: Fen ve teknoloji dersi, ögrenci görüşleri, yapılandırmacı öğrenme ortamı,

\begin{abstract}
In Turkey, constructivism has been an underlying theme of the educational reforms in last decades. The purpose of this study is to examine Turkish middle students' perspectives on the constructivist learning environment in a science course in terms of gender and students' age. The ACLE was administered to a sample of 1882 students from grades 6-8 randomly selected in Trabzon Province in Turkey. The findings revealed that there were statistically significant differences between girls' and boys' views on dimensions of ACLE, including student centered, thought provoking, life relevance, concurrent learning and assessment, and bringing different viewpoints. Also, in terms of students' grade, statistically significant differences were found on students' view on dimensions of ACLE. The educational implications of the results were discussed.
\end{abstract}

Evaluation of 6th, 7th and 8th Grade Science and Technology Learning Environment

Keywords: Constructivist learning environment, students' perception, science and technology education

Bu araştırmada elde edilen bulguların bir bölümü veya tamamı 28-31 Mayıs 2015 tarihleri arasından düzenlenen "7. Uluslararası Eğitim Araştırmaları Kongresi” adlı konferansta sözlü bildiri olarak sunulmuştur. 


\section{Giriş}

Son çeyrek yüzyılda dünyada yaşanan hızlı değişim ve bazı yenilik hareketleri, her alanda olduğu gibi eğitim alanında da değişimi, dönüşümü ve bir takım yenilikleri beraberinde getirmiştir. Pek çok ülkede 1980 sonrasında bir takım köklü yenilik hareketleri başlatılmış ve yeni öğretim programları hazırlanmıștır. Ülkemizde de 1983, 1990 ve 1998 yıllarında genel olarak öğretim programlarında, özelde ise matematik programlarında değişikliğe gidilmiştir. Son olarak 2004 yılında dünyadaki değişim ve gelişimlere paralel olarak; Türkiye'de uygulanmakta olan öğretim programlarının değerlendirilmesi yapılmış, yeni anlayış ve uygulamaları getiren bir öğretim programı hazırlanmıştır (MEB, 2005). Böylelikle öğretmen merkezli ve öğrenmenin etki-tepki şeklinde gerçekleştiğini savunan davranışçı öğretim programlarından, bireyin bilgiyi zihninde aktif olarak kendisinin yapılandırdığını savunan öğrenci merkezli yapılandırmacı öğretim programlarına doğru bir geçiş yaşanmıştır (Şeker, 2007).

Yapılandırmacı öğrenmenin gerçekleşebilmesi için uygun öğrenme ortamlarının hazırlanması gereklidir. Yapılandırmacı öğrenme ortamının temel öğesi öğrenendir. Bu yaklaşımda demokratik olması gereken sınıf ortamı; öğrencileri motive etmeli, konuya ilgilerini çekmek için öğrenmeye uygun olarak düzenlenmeli ve günlük yaşam problemlerinin karmaşıklığını çözerek yaşam boyu kullanacakları bilgileri oluşturmalıdır (Şaşan, 2002). Bunun yanında bireylerin çevresiyle daha fazla etkileşim içerisinde olmasını, zihinsel süreç yaşamasına imkân tanımasını, dolayısıyla zengin öğrenme yaşantıları geçirmelerine olanak sağlayacak şekilde düzenlenmesini gerektirmektedir (Şimşek, 2004). Çünkü işbirliğine dayalı öğrenme ortamlarında, öğrenciler hem kendi hedeflerini gerçekleştirmede destek bulmakta hem de grup içerisinde yer alan öğrencilere yardım etmekte ve birbirini cesaretlendirmektedir (Küçüközer, Bostan, Kenar, Seçer, ve Yavuz, 2008). Bu tür öğrenme ortamlarının en iyi şekilde oluşturulabildiği derslerden biri olarak ise fen ve teknoloji dersi karşımıza çıkmaktadır. Çünkü öğrencilerin öğrenme öğretme sürecinde fen ve teknoloji dersinde daha çok sorumluluk almalarına ve etkin olmalarına olanak sağlayan işbirliğine ve probleme dayalı öğrenme ortamları oluşmaktadır (Brooks ve Brooks, 1993). Yapılan çalışmalar, öğrencilerin yapılandırmacı öğrenme ortamının akademik başarısına direkt ve dolaylı etki yaptığını rapor etmiştir (Hofstein ve Lazarowitz, 1986). Bu yüzden öğrencilerin yapılandırmacı öğrenme ortamları hakkında görüşlerini incelemek önemlidir. Bu araştırmanın amacı, yapılandırmacı öğretim anlayışı doğrultusunda geliştirilen ve 2005 yılında kademeli olarak uygulamaya konan öğretim programı çerçevesinde ilköğretim II. kademe öğrenci görüşleri doğrultusunda fen ve teknoloji dersi öğrenme ortamlarının değerlendirilmesi amaçlanmıştır. Bunun için cinsiyet ve sınıf düzeyi değişkenleri kullanılarak derse ait yapılandırmacı öğrenme ortamları hakkında değerlendirme yapılmıştır.

\subsection{Illgili alanyazın}

Geçmişten günümüze kadar geçen sürede bilginin doğasına ilişkin kabullerin farklılaşması sonucunun öğrenme ve öğretme sürecini etkilediği, buna bağlı olarak öğretim programlarının değiştirildiği ya da yenilendiği bilinmektedir. Öğrenmenin etki-tepki şeklinde gerçekleştiğini savunan davranışçı öğrenme kuramı, öğrenmenin bir zekâ ürünü olduğunu ve öğrenmede zihindeki şemaların rol oynadığını savunan bilişsel öğrenme kuramı, J. Piaget'in zihinsel gelişim teorisine dayandırılarak ortaya atılan yapısalcı öğrenme kuramı öğretim programları hazırlanırken temel alınan kuramlardan bazılarıdır.

Programın 2005 yılında uygulanmaya başlanmasıyla birlikte fen ve teknoloji dersi ile fen öğretimine yönelik çalışmalar da hız kazanmıştır. Bu kapsamda özellikle son beş yıl içerisinde birçok araştırma yapılmıştır. Yapılan araştırmalar incelendiğinde genel olarak fen öğretiminde yapılandırmacı yaklaşımın çeşitli değişkenler (başarı, motivasyon, tutum vb...) üzerine etkileri, fen ve teknoloji dersine yönelik öğretmen ve öğrenci görüşleri ve bu derse ait öğretim materyallerinin değerlendirilmesi şeklindedir (Küçüközer, Bostan, Kenar, Seçer ve Yavuz, 2008; Şeker, 2007; Yaman ve Dede, 2006; Dede ve Yaman, 2007; Çakır, Şenler, ve 
Taşkın 2007; Aktepe ve Aktepe, 2008; Balım vd., 2009; Nuhoğlu, 2008; Bulut, Güven ve Güzel, 2009; Gömleksiz ve Bulut, 2006; Tüysüz ve Aydın, 2009; Çeken, 2010; Yılmaz Kaya, 2008; Uzun ve Keleş, 2010; Balc1, 2007; Özgür, 2008; Demirci, 2009). Öğretim programlarının öğretmen nitelikleri, öğrenci nitelikleri ve sınıf özellikleri üzerine yansımaları da araştırılan konular arasında yer almaktadır. Yapılandırmacı öğrenme ortamlarının değerlendirilmesine yönelik çalışmalar incelendiğinde yurt dışında genel olarak kullanılan iki ölçeğe rastlanmaktadır. Taylor, Fraser ve White'nin hazırladığı ölçek; yaşamla ilişkilendirme, öğrenme sorumluluğunu alma, bilginin değişebilirliğini kavrama, işbirliği yapma ve eleştirel düşünme olmak üzere 5 boyuttan oluşmaktadır (Taylor, Fraser ve White, 1994). Tenenbaum, Naidu, Jegede ve Austin'in hazırladığı ölçek ise; tartışmalar ve görüşmeler, kavramsal çelişkiler, düşünceleri diğerleriyle paylaşma, materyal ve kaynakların çözüme odaklı olması, yansıma ve kavram araştırması için motivasyon, öğrenen ihtiyaçlarını karşılama, anlamlandırma ve gerçek yaşam örnekleri olmak üzere 7 boyuttan oluşmaktadır (Tenenbaum, Naidu, Jegede ve Austin; 2001). Yurt içinde ise yapılandırmacı öğrenme ortamlarının değerlendirilmesine yönelik olarak Arkün ve Aşkar'ın (2010) hazırladığg ölçek ile Fer ve Cırık'ın (2006) Tenenbaum ve diğerlerinden Türkçeye uyarladığı ölçek bulunmaktadır.

Yapılandırmacı öğrenme ortamlarının oluşturulabilmesinde şüphesiz ders kitaplarının da katkısı önemlidir. Küçüközer, Bostan, Kenar, Seçer ve Yavuz (2008) fen ve teknoloji ders kitaplarının yapılandırmacı öğrenme kuramına göre değerlendirilmesi çalışmasında; bu derse ait kitapların yapılandırmacı öğrenme kuramının gereklerine uygun olduğu sonucuna ulaşmışlardır. Yani fen ve teknoloji dersine ait materyallerin de yapılandırmacı öğrenme ortamlarının oluşmasında olumlu yönde katkıda bulunduğu söylenebilir.

Öğrenci merkezli öğretim programlarının temel olarak aldığı ve öğrenme felsefesi olarak yapılandırmacılık; 18. yüzyılda insanların, kendi kendilerine ne yapılandırılırsa onu anlayabildiklerini söyleyen felsefeci Giambatista Vico'nun çalışmalarına kadar uzanır (Yapıcı ve Leblebicier, 2007). Vico 1710 'da "Bir şeyi bilen, onu açıklayabilendir" şeklindeki ifadesi ile aslında yapılandırmacılığı savunmaktadır (Çınar,Teyfur, ve Teyfur, 2006). Daha sonra İ. Kant bu düşünceyi daha da geliştirerek, bilgiyi almada insanın pasif olmadığını dile getirmiştir. Bugüne dek ulaşan yapılandırmacılık anlayışı ise J. Piaget, J. Dewey ve Vygotsky'nin fikirleri ile şekillenmiştir (Özden, 2006; Yapıcı ve Leblebicier, 2007). Yapılandırmacı öğrenme; bilgiyi araştırma, yorumlama ve analiz etme; bilgiyi ve düşünme sürecini geliştirme; geçmişteki yaşantılarla yeni yaşantıları bütünleştirme olmak üzere üç durumu temele almaktadır (Şaşan, 2002). Yapılandırmacı öğrenmede öğrenen sadece okumak ve dinlemek yerine tartışma, fikirleri savunma, hipotez kurma, sorgulama ve fikirleri paylaşma gibi öğrenme sürecine etkin katılım yoluyla öğrenme gerçekleştirir.

Arkün ve Aşkar'ın (2010) geliştirmiş olduğu ölçek; öğrenci merkezli, düşündüren, işbirlikli, yaşamla ilgili, öğretim ve değerlendirmenin bir aradalığı, farklı bakış açıları olmak üzere 6 boyuttan oluşmaktadır (Arkün ve Aşkar, 2010). Bu boyutlar şu şekildedir:

Öğrenci Merkezli: Yapılandırmacı yaklaşıma göre bilgi birey tarafından yapılandırılır. Bu sebeple ortamda aktif olması gereken öğrenendir.

Düşündüren: Bireyin, bir bilgiyi soruşturabilmesi için sorgulaması gerekmektedir. Yani öğrenen bilgiyi anlamlandırma çabası içine girmelidir.

İşbirlikli: İşbirliği ve bunun sonucunda oluşan iletişim yapılandırmacı öğrenme ortamlarının 2 özelliğindendir. İletişim ve sosyal etkileşim düşünmeyi ilerletmekle beraber, bilgi yapılandırmasında önemli bir faktördür.

Yaşamla ilgili: Öğrenme ortamlarında gerçek problemler üzerinde durulması, öğrencilerin deneyim kazanması ve bilgiyi yapılandırmasını sağlamaktadır. 
Öğretim ve değerlendirmenin bir aradalı̆̆g: Öğrenme gelişmenin sonucu değil, gelişmenin kendisidir. Bu sebeple ölçülmesi gereken yalnız sonuç değil, aynı zamanda süreçtir.

Faklı bakış açıları: Öğrencilerin yapması gereken, öğretmenlerin gözünden dünyayı görmek değil, kendi bakış açılarını oluşturmaktır. Öğrencilere farklı bakış açıları kazandırılmalı ve değişik yollardan çözüme ulaşma konusunda cesaretlendirilmelidir.

Görüldüğü üzere alanyazında yapılandırmacı öğrenme ortamlarının değerlendirilmesine yönelik ülkemizde sadece bir, yurt dışında ise birkaç ölçeğe rastlandığı söylenebilir. Arkün ve Aşkar'ın hazırlamış olduğu ölçek araştırmaya uygun olmakla beraber daha önce hiç kullanılmamış olması ve bu alanda çok az sayıda araştırma yapılmış olması sebebiyle tercih edilmiştir.

\subsection{Araştırmanın amact}

Yapılandırmacı yaklaşımda tasvir edilen öğrenme ortamları ve bu alanda yapılan çalışmalar ışığında araştırmanın temel içeriği olarak; "İlköğretim II. kademe fen ve teknoloji dersi yapılandırmacı öğrenme ortamlarının öğrenci görüşleri doğrultusunda değerlendirilmesi” şeklinde olmasına karar verilmiştir. Bu bağlamda araştırmada aşağıdaki problemlere cevap aranmıştır:

1. Fen ve teknoloji dersine ait yapılandırmacı öğrenme ortamları cinsiyete göre farklılaşmakta mıdır?

2. Fen ve teknoloji dersine ait yapılandırmacı öğrenme ortamları sınıf düzeyine göre farklılaşmakta mıdır?

\section{Yöntem}

Araştırma, deneysel olmayan nicel araştırma tasarımına sahiptir ve tarama modeline dayalı olarak yürütülmüştür (Arlı ve Nazik, 2001).

\subsection{Araştırmanin örneklemi}

Araştırmada, örneklemden veri toplamak amacıyla survey modeli kullanılmıştır (Cohen, Manion ve Morrison, 2000). Örneklemden veri toplamada ise anket tekniği kullanılmıştır. Anket deneklerin görüşlerinin yazılı olarak alındığı bir veri toplama tekniğidir (Arseven, 1994). Araştırmanın örneklemini Trabzon ili sınırları içerisinde yer alan rastgele seçilmiş 20 okulda öğrenim gören 1882 ilköğretim II. kademe öğrencisi oluşturmaktadır. Tablo 1'de öğrencilerin bazı özellikleri özetlenmiştir.

Tablo 1. Örneklemin Özellikleri

\begin{tabular}{llll}
\hline Sinıf Düzeyi & & Cinsiyet & \\
\hline 6. sinıf & 647 & Kiz & 915 \\
7. Sinıf & 621 & Erkek & 967 \\
8. Sinıf & 614 & & \\
\hline
\end{tabular}

\subsection{Veri toplama aracı}

Araştırmaya konu olan yapılandırmacı öğrenme ortamlarının değerlendirilmesine yönelik olarak Arkün ve Aşkar (2010) tarafından geliştirilen, geçerlik ve güvenirlik çalışmaları yine kendileri tarafından yapılan "yapılandırmacı öğrenme ortamlarını değerlendirme ölçeği”" kullanılmıştır. Ölçek, daha öncede belirtilen altı ölçüt doğrultusunda 28 maddeden oluşan yedili likert tipinde bir ölçektir. Ölçeğin ilköğretim ikinci kademe öğrencilerine uygulanacağı 
dikkate alınarak her bir maddeye verilen cevap sayısı daha anlaşılır olabilmesi açısından 7'den 5'e düşürülmüştür. 6 ölçüte ait maddeler aşağıdaki gibidir:

1. ölçüt; Öğrenci Merkezli: Madde2, Madde4, Madde11, Madde18

2. ölçüt; Düşündüren: Madde1, Madde6, Madde12, Madde17, Madde23, Madde24, Madde25

3. ölçüt; İşbirlikli: Madde3, Madde7, Madde13, Madde19

4. ölçüt; Yaşamla İlgili: Madde8, Madde14, Madde20, Madde26

5. ölçüt: Öğretim ve Değerlendirmenin Bir Aradalı̆̆ı: Madde9, Madde14, Madde21, Madde27

6. ölçüt; Farklı Bakış Açıları: Madde4, Madde10, Madde16, Madde22, Madde28

Ölçeğin giriş kısmına araştırmanın amacı doğrultusunda bağımsız değişkenler eklenmiştir. Ölçeğin geçerlilik analizi için AMOS 18 programı ile Doğrulayıcı Faktör Analizi (DFA) yapılmıştır (Aytaç ve Öngen). Hu ve Bentler (1999) DFA uyumluluk indeksleri için RMSEA $<0.06$ ve CFI $>0.95$ değerlerinin kabul edilebilir olduğunun belirtmiştir. Buna göre ilk DFA sonuçları istenilen düzeyde değildi $\left(\chi^{2}(335, \mathrm{~N}=1882)=1186.13, \mathrm{p}<.001\right.$, RMSEA $=.065, \mathrm{CFI}=.89)$. Cabrera-Nguyen (2010) faktör yük değeri 0.30 'dan küçük olan maddelerin DFA'dan çıarılmasını önermiştir. Bu yüzden Madde7 ve Madde21 0.30'dan düşük faktör yüküne sahip olmaları nedeniyle çıkarılmıştır (sırasıyla 0,17 ve 0,28 ). Geriye kalan 26 madde ile yapılan DFA kabul edilebilir düzeyde sonuçlar vermiştir $\left(\chi^{2}(284, \mathrm{~N}=1882)=960.51, \mathrm{p}<\right.$ .001 , RMSEA $=.036, \mathrm{CFI}=.95$ ). Ölçeğin güvenilirlik analizi için ise Cronbach alfa değerleri hesaplanmıştır. Tüm faktörlerin Cronbach alfa değerleri 0.69 ile 0.84 arasında değişmiştedir ve kabul edilebilir düzeydedir. Tablo 2'de tüm faktörlerin Cronbach alfa değerleri verilmiştir.

Tablo 2. Faktörlerin güvenirlik katsayısı ve örnek madde

\begin{tabular}{|c|c|c|c|}
\hline Faktör & Örnek madde & Güvenirlik & $\begin{array}{l}\text { Madde } \\
\text { sayıs! }\end{array}$ \\
\hline Öğrenci merkezli & $\begin{array}{l}\text { Kendi öğrenmemle ilgili kararları ben } \\
\text { veriyorum. }\end{array}$ & .72 & 4 \\
\hline Düşündüren & $\begin{array}{l}\text { Dersle ilgili sorularımın cevaplarını } \\
\text { araştırarak buluyorum. }\end{array}$ & .78 & 7 \\
\hline İşbirlikci & $\begin{array}{l}\text { Derste arkadaşlarımla işbirliği içinde } \\
\text { çalışıyoruz. }\end{array}$ & .70 & 3 \\
\hline Yaşamla ilgili & $\begin{array}{l}\text { Öğrendiklerimi nerede } \\
\text { uygulayabileceğimi biliyorum. }\end{array}$ & .69 & 4 \\
\hline $\begin{array}{l}\text { Öğgretim ve } \\
\text { değerlendirmenin } \\
\text { bir aradalığı }\end{array}$ & $\begin{array}{l}\text { Dersin değerlendirme kısmını, öğretici } \\
\text { nitelikte buluyorum. }\end{array}$ & .84 & 3 \\
\hline Faklı bakış açıları & $\begin{array}{l}\text { Derste karşılaştı̆̆ım soruların, birden } \\
\text { fazla doğru cevabı olabileceğini } \\
\text { görüyorum. }\end{array}$ & .83 & 5 \\
\hline
\end{tabular}

\subsection{Verilerin analizi ve yorumlanması}

Verilerin analizi SPSS 21 paket programı kullanılarak yapılmıştır. Ölçeğin uygulanması ile elde edilen verilerin analizinde iki farklı istatistiksel teknik kullanılmıştır. Bu analizler araştırmanın sorularının cevaplanmasına yönelik MANOVA testi yapılmıştır. Eğer MANOVA test sonucunda elde edilen $\mathrm{F}$ değerinin anlamlı bulunması durumunda bunun hangi faktörlerde olduğunu bulmak amacıyla ANOVA yapılmıştır. MANOVA testi yapılmadan önce gruptaki kişi sayıları eşit olmadığı durumlarda varyansların homojenliği testinin yapılmasının önerilmektedir (Tabachnick ve Fidell, 2013).. Bu çalışmanın 
örneklemindeki cinsiyet ve sınıf düzeyi gruplarındaki öğrenci sayıları eşit olmadığı için varyansların homojenliği Box $\mathrm{M}$ testi le test edilmiş ve anlamlı farklılık bulunamamıştır (sınıf düzeyi için $\mathrm{F}(42)=1.21$, $\mathrm{p}=0.16$ ve cinsiyet için $\mathrm{F}(21)=1.01$, $\mathrm{p}=0.34$ ). Bu yüzden gruplar arasındaki sayı farklılığı MANOVA testi için ihmal edilebilir (Tabachnick ve Fidell, 2013).

\section{Bulgular}

Araştırmanın bu bölümünde elde edilen bulgular, belirlenen problemler doğrultusunda sırasıyla verilmekte ve tartışılmaktadır. Tablo 3 'te öğrencilerin yapılandırmacı öğrenme ortamlarına ilişkin görüşleri verilmiştir.

Tablo 3. Yapılandırmacı öğrenme ortamlarını değerlendirme puanlarının değişkenlere göre ortalamaları ve standart sapmaları

\begin{tabular}{|c|c|c|c|c|c|c|}
\hline & \multicolumn{3}{|c|}{ Sınıf Düzeyi } & \multicolumn{2}{|c|}{ Cinsiyet } & \multirow[t]{2}{*}{ Tüm } \\
\hline & 6. sinif & 7. $\sin 1 f$ & 8. sinif & $\mathrm{K} 1 \mathrm{z}$ & Erkek & \\
\hline ÖM & $3,82(0,7)$ & $3,64(0,7)$ & $3,58(0,7)$ & $3,75(0,7)$ & $3,63(0,8)$ & $3,69(0.7)$ \\
\hline DÜ & $3,87(0,7)$ & $3,73(0,7)$ & $3,62(0,7)$ & $3,83(0,6)$ & $3,67(0,7)$ & $3,74(0.7)$ \\
\hline İB & $3,31(0,6)$ & $3,32(0,6)$ & $3,28(0,6)$ & $3,33(0,6)$ & $3,30(0,6)$ & $3,31(0.6)$ \\
\hline YI & $3,97(0,8)$ & $3,89(0,8)$ & $3,80(0,9)$ & $4,00(0,8)$ & $3,80(0,8)$ & $3,89(0.8)$ \\
\hline ÖD & $3,56(0,6)$ & $3,52(0,6)$ & $3,48(0,6)$ & $3,59(0,6)$ & $3,45(0,6)$ & $3,52(0.6)$ \\
\hline FB & $3,97(0,7)$ & $3,81(0,7)$ & $3,70(0,6)$ & $3,92(0,7)$ & $3,74(0,8)$ & $3,83(0.7)$ \\
\hline
\end{tabular}

Not: 5'li Likert üzerinden hesaplanmış ve standart sapma değerleri parantez içerisinde gösterilmiştir. ÖM= Öğrenci Merkezli, DÜ= Düşündüren, İB=İ̧̧birlikli, Yİ= Yaşamla İlgili, ÖD= Öğretim ve Değerlendirmenin Bir Aradalığı, FB= Farklı Bakış Açıları,

Tablo 3’teki sonuçlara göre, tüm öğrencilerin ortalama değerlerine bakıldığında, fen ve teknoloji dersini ait yapılandırmacı öğrenme ortamına ilişkin orta ile yüksek seviye arasında görüşlere sahip oldukları söylenebilir (1- düşük, 3-orta ve 5-yüksek). Ayrıca öğrenciler fen ve teknoloji dersi sınıf ortamını diğer alt-boyutlar arasında en düşük işbirlikçi olarak değerlendirmişlerdir. Yaşamla ilgili olma alt boyutu ise öğrenciler tarafından en yüksek olarak değerlendirilmiştir.

\subsection{Cinsiyete ilişkin bulgular}

İlköğretim II. kademe öğrencilerinin fen ve teknoloji dersine ait yapılandırmacı öğrenme ortamları cinsiyete göre değerlendirilmiştir. Tablo 3'teki sonuçlara göre, kız ve erkek öğrencilerin fen ve teknoloji dersini ait yapılandırmacı öğrenme ortamına ilişkin orta ile yüksek seviye arasında görüşlere sahip oldukları söylenebilir. Kız öğrenciler fen ve teknoloji dersi sınıf ortamını diğer alt-boyutlar arasında en düşük işbirlikçi olarak değerlendirmişlerdir $(\overline{\mathrm{X}}=3,33, \mathrm{SD}=0,6)$. Yaşamla ilgili olma alt boyutu ise öğrenciler tarafindan en yüksek olarak değerlendirilmiştir $(\overline{\mathrm{X}}=4,00, \mathrm{SD}=0,8)$. Kız öğrenciler gibi, erkek öğrenciler de fen ve teknoloji dersini ait yapılandırmacı öğrenme ortamını en düşük işbirlikçi $(\overline{\mathrm{X}}=3,31, \mathrm{SD}=0,6)$ ve en yüksek yaşamla ilgili olma olarak değerlendirmişlerdir $(\overline{\mathrm{X}}=3,89, \mathrm{SD}=0,8)$.

Fen ve teknoloji dersine ait yapılandırmacı öğrenme ortamlarının cinsiyete göre değişimi MANOVA testi ile incelenmiştir. Tablo 4'teki sonuçlara göre fen ve teknoloji dersini ait yapılandırmacı öğrenme ortamına ilişkin görüşlerin cinsiyete göre anlamlı değişkenlik elde edilmiştir $(\lambda=, 977, \mathrm{~F}=7,498 ; \mathrm{p}<, 001)$. 
Tablo 4: Yapılandırmacı öğrenme ortamlarını değerlendirme puanlarının cinsiyete göre MANOVA sonuçları

\begin{tabular}{lccccc}
\hline & $\boldsymbol{\lambda}$ & $\mathbf{F}$ & Hipotez Sd & Hata Sd & p \\
\hline Wilks' Lambda &, 977 & 7,498 & 6,000 & 1872,000 &, $000^{*}$ \\
\hline
\end{tabular}

Hangi alt boyutta anlamlı farklılık olduğunu anlamak amacıyla ANOVA testi yapılmıştır. ANOVA testi sonuçlara göre, kız öğrenciler fen ve teknoloji dersi öğrenme ortamını öğrenci merkezli, düşündüren, yaşamla ilgili, öğretim ve değerlendirmenin bir aradalığ 1 ve farklı bakış açıları yönünden erkek öğrencilerden daha yüksek olarak değerlendirmiştir (Tablo 5). Kız ve erkek öğrenciler arasında fen ve teknoloji dersi öğrenme ortamının işbirlikli $(\mathrm{F}[1,1881]=0,4956, \mathrm{p}>.05)$ alt boyutunda anlamlı bir farklılık görülmemiştir.

Tablo 5: Yapılandırmacı öğrenme ortamlarını alt boyutları değerlendirme puanlarının cinsiyete göre ANOVA sonuçları

\begin{tabular}{lccccc}
\hline & $\begin{array}{c}\text { Kareler } \\
\text { toplamı }\end{array}$ & df & $\begin{array}{c}\text { Kareler } \\
\text { ortalamasi }\end{array}$ & F & $\boldsymbol{p}$ \\
\hline ÖM & 7,250 & 1 & 7,250 & 13,199 &, $000^{*}$ \\
DÜ & 11,573 & 1 & 11,573 & 25,981 &, $000^{*}$ \\
IB & 0,349 & 1 & 0,349 & 0,956 &, 328 \\
Yİ & 18,517 & 1 & 18,517 & 29,463 &, $000^{*}$ \\
ÖD & 9,082 & 1 & 9,082 & 24,128 &, $000^{*}$ \\
FB & 16,198 & 1 & 16,198 & 33,351 &, $000^{*}$ \\
\hline
\end{tabular}

Not: ÖM= Öğrenci Merkezli, DÜ= Düşündüren, İB=İşbirlikli, Y $\mathrm{I}=$ Yaşamla İlgili, ÖD= Öğretim ve Değerlendirmenin Bir Aradalı̆̆ı, FB= Farklı Bakış Açıları, * $p<, 001$

\subsection{Sinıf düzeyine ilişkin bulgular}

Öğrencilerinin fen ve teknoloji dersine ait yapılandırmacı ögrenme ortamları hakkında görüşleri sınıf düzeyine göre değerlendirilmiştir. Tablo 3'teki sonuçlara göre, her bir sınıf düzeyindeki öğrencilerin fen ve teknoloji dersini ait yapılandırmacı öğrenme ortamına ilişkin orta ile yüksek seviye arasında görüşlere sahip oldukları söylenebilir. Diğer bulgulara paralel olarak, fen ve teknoloji dersi ortamını her sınıf düzeyinde en düşük işbirlikçi (6. sınıf için $\bar{X}=$ 3,31, $\mathrm{SD}=0,6,7$. sinıf için $\overline{\mathrm{X}}=3,32, \mathrm{SD}=0,6$ ve 8. sınıf için $\overline{\mathrm{X}}=3,28, \mathrm{SD}=0,6$ ) olarak değerlendirmişlerdir. Buna ek olarak, her sınıf düzeyinde öğrenciler fen ve teknoloji dersi öğrenme ortamını en yüksek yaşamla ilgili olma alt boyutunda değerlendirmişlerdir (6. sınıf için $\overline{\mathrm{X}}=3,97, \mathrm{SD}=0,8,7$. sinıf için $\overline{\mathrm{X}}=3,89, \mathrm{SD}=0,8$ ve 8 . sinıf için $\overline{\mathrm{X}}=3,80, \mathrm{SD}=0,9)$.

Fen ve teknoloji dersine ait yapılandırmacı öğrenme ortamlarının sınıf düzeyine göre değişimi MANOVA testi ile incelenmiştir. Tablo 6'teki sonuçlara göre fen ve teknoloji dersini ait yapılandırmacı öğrenme ortamına ilişkin görüşlerin sınıf düzeyine göre anlamlı değişkenlik elde edilmiştir $(\lambda=, 965, \mathrm{~F}=5,570 ; \mathrm{p}<, 001)$.

Tablo 6: Yapılandırmacı öğrenme ortamlarını değerlendirme puanlarının sınıf düzeyine göre

\begin{tabular}{cccccc}
\hline \multicolumn{8}{c}{ MANOVA sonuçları } \\
\hline Wilks' Lambda & $\boldsymbol{\lambda}$ & $\mathbf{F}$ & Hipotez Sd & Hata Sd & $\mathbf{p}$ \\
\hline
\end{tabular}

Hangi alt boyutta anlamlı farklılık olduğunu anlamak amacıyla ANOVA testi yapılmıştır (Tablo 7). ANOVA testi sonuçlara göre, 6. sınıf öğrenciler fen ve teknoloji dersi öğrenme ortamını öğrenci merkezli, düşündüren, yaşamla ilgili ve farklı bakış açıları yönünden 7. ve 8 . sınıf öğrencilerden daha yüksek olarak değerlendirmiştir. Sınıf düzeyleri arasında öğrenciler arasında fen ve teknoloji dersi öğrenme ortamının işbirlikli $(F[2,1879]=0,556, p>.05)$ ve öğretim ve değerlendirmenin bir aradalığı $(F[2,1879]=2,318, \mathrm{p}>.05)$ alt boyutlarında anlamlı bir farkl1lık görülmemiştir. 
Tablo 7: Yapılandırmacı öğrenme ortamlarını alt boyutları değerlendirme puanlarının sınıf düzeyine göre ANOVA sonuçları

\begin{tabular}{lrrrrr}
\hline & $\begin{array}{c}\text { Kareler } \\
\text { toplamı }\end{array}$ & df & $\begin{array}{c}\text { Kareler } \\
\text { ortalaması }\end{array}$ & \multicolumn{1}{c}{ F } & \multicolumn{1}{c}{$\boldsymbol{p}$} \\
\hline ÖM & 19,867 & 2 & 9,933 & 18,299 &, $000^{*}$ \\
DÜ & 19,138 & 2 & 9,569 & 21,667 &, $000^{*}$ \\
İB & 0,406 & 2 & 0,203 & 0,556 &, 573 \\
Y் & 9,115 & 2 & 4,558 & 7,191 &, $000^{*}$ \\
ÖD & 1,764 & 2 & 0,882 & 2,318 &, 099 \\
FB & 21,304 & 2 & 10,652 & 22,044 &, $000^{*}$ \\
\hline
\end{tabular}

Not: ÖM= Öğrenci Merkezli, DÜ= Düşündüren, İB=İşbirlikli, Yİ= Yaşamla İlgili, ÖD= Öğretim ve Değerlendirmenin Bir Aradalığı, FB= Farklı Bakış Açıları, * $p<, 001$

Bunlara ek olarak, sınıf düzeyindeki anlamlı farklılı̆ıın kaynağını tespit etmek amacıyla Post Hoc Testlerinden Tukey HSD analizi yapılmış ve analiz sonuçlarına göre öğrenci merkezli alt faktöründe 6. sınıfta okuyan öğrencilerin, 7. ve 8. sinıfta okuyan öğrencilere göre $\mathrm{p}<0.001$ anlam düzeyinde farklılık gösterdiği gözlenmiştir. Düşündüren alt faktöründe ise, 6 . sınıfta okuyan öğrenciler, 7. sinıfta okuyan öğrencilere göre $p<0,05,8$. sinıfta okuyan öğrencilere göre ise $\mathrm{p}<0,001$ anlam düzeyinde farklılaşmıştır. Yaşamla ilgili alt faktöründe ise, 6 . sınıfta okuyan öğrencilerin, 8 . sinıfta okuyan öğrencilere göre $\mathrm{p}<0,001$ anlam düzeyinde farklılık gösterdiği gözlenmiştir. Son olarak farklı bakış açıları alt faktöründe ise, 6.sınıfta okuyan ögrencilerin, 7.ve 8. sinıfta okuyan öğrencilere göre $\mathrm{p}<0,001$ anlam düzeyinde farklılık gösterdiği gözlenmiştir.

\section{Sonuç ve Öneri}

Cinsiyet ve sınıf düzeyi değişkenlerinin öğrencilerin fen ve teknoloji dersine ait yapılandırmacı öğrenme ortamları ve alt boyutları olan öğrenci merkezli, düşündüren, işbirlikli, yaşamla ilgili, öğretim ve değerlendirmenin bir aradalığı ve farklı bakış açılarına yönelik öğrenci görüşlerinin değerlendirildiği bu çalışmada aşağıdaki sonuçlara ulaşılmıştır.

Cinsiyet durumuna göre faktör bazında yapılan tek yönlü ANOVA sonuçların göre; öğrenci merkezli, düşündüren, yaşamla ilgili, öğretim ve değerlendirmenin bir aradalığı ve farklı bakış açıları faktörlerinde cinsiyete göre anlamlı farklılık gözlenirken, işbirlikli faktöründe anlamlı bir fark bulunamamıştır. Öğrenci merkezli, düşündüren, yaşamla ilgili, öğretim ve değerlendirmenin bir aradalı̆̆g ve farklı bakış açıları alt faktöründe farklılığın kaynağı kızların erkeklere göre değerlendirme puanlarının daha yüksek olduğudur. İşbirlikli faktöründe kız öğrencilerin puanlarının erkeklere göre yüksek ancak istatistiksel olarak anlamlı olmadığı tespit edilmiştir. Cinsiyet ile fen bilgisi dersine yönelik tutum puanları arasında anlamlı bir farklılık gözlenmemiştir (Çakır, Şenler ve Taşkın, 2007). Cinsiyet değişkeninin öğrencilerin fen ve teknoloji dersine yönelik motivasyonları üzerinde etkili olduğunu göstermektedir. Kız öğrencilerin motivasyon düzeyleri erkek öğrencilere göre daha yüksektir (Dede ve Yaman, 2007).

Sınıf düzeyi durumuna göre faktör bazında yapılan tek yönlü ANOVA sonuçlarına göre; öğrenci merkezli, düşündüren, yaşamla ilgili ve farklı bakış açıları faktörlerinde sınıf düzeyine göre anlamlı bir farklılık gözlenmiştir. Anlamlı farklılığın kaynağı 6. sınıfta okuyan ögrencilerin, 7. ve 8. sınıfta okuyan öğrencilere göre değerlendirme puanlarının daha yüksek olduğudur. Öğrencilerin sınıf düzeyi arttıkça, öğrenci merkezli öğrenme ortamlarında azalma olduğu tespit edilmiştir. Düşündüren alt faktöründe; 6. sinıfta okuyan öğrencilerin, 7. ve 8. sınıfta okuyan öğrencilere göre değerlendirme puanlarının daha yüksek olduğudur. Öğrencilerin sınıf düzeyi arttıkça, düşündüren öğrenme ortamlarında azalma olduğu tespit edilmiştir. Yaşamla ilgili alt faktöründe; 6. sınıfta okuyan öğrencilerin, 8. sinıfta okuyan öğrencilere göre değerlendirme puanlarının daha yüksek olduğudur. Öğrencilerin sınıf düzeyi arttıkça, yaşamla ilgili öğrenme ortamlarında azalma olduğu tespit edilmiştir. Farklı bakış açıları alt faktöründe ise; 6 .sınıfta okuyan öğrencilerin, 7.ve 8. sınıfta okuyan öğrencilere göre 
değerlendirme puanlarının daha yüksek olduğu gözlenmiş. Öğrencilerin sınıf düzeyi arttıkça, farklı bakış açıları öğrenme ortamlarında azalma olduğu tespit edilmiştir. Öğrencilerin sınıf düzeyleri ile fen bilgisi dersine yönelik tutum puanları arasındaki ilişkinin analizine göre 6 . sinıf ile 7. ve 8.sınıf arasında 6. sınıfta öğrenim gören öğrenciler lehine anlamlı bir farklılık varken, 7. ve 8. sınıf arasında anlamlı bir farklılık gözlenmemiştir (Çakır, Şenler ve Taşkın, 2007). Öğrencilerin sınıf düzeyi ile fen ve teknoloji dersine yönelik motivasyon düzeyleri 6 . sınıf öğrencilerin lehine olmuştur. Ortalama puanlar incelendiğinde, genel bir eğilim olarak öğrencilerin sınıf seviyesi arttıkça fen dersine yönelik motivasyon düzeylerinin azaldığı gözlenmiştir (Dede ve Yaman, 2007). Yeni eğitim programına göre öğrenim gören öğrencilerin eski programda yetişen öğrencilere göre dersi sevmeleri yönünden anlamlı bir fark gösterdiği sonucuna ulaşılmıştır. Olumsuz tutum ortalamaları bakımından gruplar arasında benzer bir dağılımın olduğu görülmüştür. Bu durum öğretmenlerin yeni programı uygulama konusunda yeterince deneyime sahip olmadığını gösterebilir (Çeken, 2010).

Yapılandırmacı öğrenme ortamlarının öğrencilerin öğrenmelerini arttırdığı düşünüldüğünde özellikle fen ve teknoloji derslerinde yapılandırmacı öğrenme ortamlarını etkileyen faktörler belirlenmeli ve bunlar öğretmen tarafından dikkate alınmalıdır. Bu araştırmanın sonuçları ışığında yapılandırmacı öğrenme ortamlarının alt faktörleri olan öğrenci merkezli, düşündüren, işbirlikli, yaşamla ilgili, öğretim ve değerlendirmenin bir aradalığ ${ }_{1}$ ve farklı bakış açıları öğrenme ortamlarının fen ve teknoloji derslerinde kullanılmasının öğrencilerin öğrenmeleri üzerinde etkili olacağı düşünülmektedir. Bunun yanında, 7. ve 8. sınıfta okuyan öğrencilerin, fen ve teknoloji dersindeki yapılandırmacı öğrenme ortamını etkileyen faktörler tespit edilmeli ve yapılandırmacı öğrenme ortamlarını arttıracak çalışmalar yapılması önerilmektedir. Erkek öğrencilerin fen ve teknoloji dersindeki yapılandırmacı öğrenme ortamına ilişkin sahip oldukları algıları tespit edilmeli ve yapılandırmacı öğrenme ortamlarını arttıracak çalışmalar yapılması önerilmektedir.

\section{Kaynakça}

Aktepe, V. ve Aktepe, Y., (2009). Fen ve teknoloji öğretiminde kullanılan öğretim yöntemlerine ilişkin öğrenci görüşleri: Kırşehir BİLSEM örneği, Ahi Evran Üniversitesi Kırşsehir Ĕ̈itim Fakültesi Dergisi, 10, 69-80.

Arkün, S. ve Aşkar, P., (2010). Yapılandırmacı öğrenme ortamlarını değerlendirme ölçeğinin geliştirilmesi, Hacettepe Üniversitesi Eğitim Fakültesi Dergisi, 39, 32-43.

Arlı, M. ve Nazik, M. H., (2001). Bilimsel araştırmaya giriş, Gazi Kitapevi, Ankara.

Arseven, A. D., (1994). Alan araştırma yöntemi, ilkeler teknikler örnekler, Gül Yayınevi, Ankara.

Aytac M, ve Öngen B, (2012). Doğrulayıcı faktör analizi ile yeni çevresel paradigma ölçeğinin yapı geçerliliğinin incelenmesi, Istatistikçiler Dergisi 5, 14-22

Balcı, A. S., (2007). Fen ögretiminde yapılandırmacı yaklaşım uygulamasının etkisi, Selçuk Üniversitesi Fen Bilimleri Enstitüsü, Yüksek Lisans Tezi, Konya.

Balım, A. G., Sucuoğlu, H. ve Aydın, G., (2009). Fen ve teknolojiye yönelik tutum ölçeğinin geliştirilmesi, Pamukkale Üniversitesi Eğitim Fakültesi Dergisi, 25, 33-41.

Brooks, J. G. ve Brooks, M. G., (1999). "The courage to be constructivist", Educational Leadership, 57, 18-24.

Bulut, İ, Güven, R. G. ve Güzel, S., (2009). Öğrencilerin yeni fen ve teknoloji dersine ilişkin tutumlarının değerlendirilmesi: Diyarbakır ili örneği, Çă̆daş Ĕgitim Dergisi, 34, 2633. 
Çakır N. K., Şenler, B. ve Taşkın, B. G., (2007). İlköğretim II. kademe öğrencilerinin fen bilgisi dersine yönelik tutumlarının belirlenmesi, Türk Eğitim Bilimleri Dergisi, 5, 637-655.

Çeken, R., (2010). İlköğretim öğrencilerinin 2005 öncesi ve sonrası uygulanan programlara göre aldıkları fen ve teknoloji eğitimine yönelik tutumu, Dicle Üniversitesi Ziya Gökalp Ĕ̈itim Fakültesi Dergisi, 14, 38-48.

Çınar, O., Teyfur, E. ve Teyfur, M., (2006). İlköğretim okulu öğretmen ve yöneticilerinin yapılandırmacı eğitim yaklaşımı ve programı hakkındaki görüşleri, İnönü Üniversitesi Eğitim Fakültesi Dergisi, 7, 47-64.

Cohen, L., Manion, L. and Morrison, K., (2000). Research methods in education, Fifth edition, Routledge/Falmer, Taylor and Francis Group, London.

Dede, Y. ve Yaman, S., (2006). İlköğretim öğrencilerinin fen ve teknoloji ile matematik dersini öğrenme tercihleri, Science and Mathematics Learning Preferences, 1, 172180 .

Dede, Y. ve Yaman, S., (2007). Öğrencilerin fen ve teknoloji ve matematik dersine yönelik motivasyon düzeylerinin bazı değişkenler açısından incelenmesi, Kuram ve Uygulamada Ĕ̈itim Yönetimi, 52, 615-638.

Demirci, C., (2009). Fen bilgisi öğretiminde yapılandırmacı öğrenme yaklaşımı, Hacettepe Üniversitesi Eğitim Fakültesi Dergisi, 37, 24-35.

Fer, S. ve Cırık, İ., (2006). Öğretmenlerde ve öğrencilerde yapılandırmacı öğrenme ortamı ölçeğinin geçerlik ve güvenirlik çalışması nedir?, Yeditepe Üniversitesi Eğitim Fakültesi Dergisi, 2, 1-27.

Gömleksiz, M. N. ve Bulut, İ., (2006). Fen bilgisi dersine ilişkin öğrenci görüşlerinin değerlendirilmesi: Diyarbakır ili örneği, Eurasian Journal of Educational Research, 23, 106-116.

Hofstein, A. \& Lazarowitz, R., (1986). A comparison of the actual and preferred classroom learning environment in biology and chemistry as perceived high school students. Journal of Research in Science Teaching, 23, 189-199.

Küçüközer, H., Bostan, A., Kenar, Z., Seçer, S. ve Yavuz, S., (2008). 6. sınıf fen ve teknoloji ders kitaplarının yapılandırmacı öğrenme kuramına göre değerlendirilmesi”, İlkögretim Online, 7, 111-126.

MEB, (2005). İlköğretim kurumları yönetmeliğinde değişiklik yapılmasına dair yönetmelik, Milli Ĕgitim Bakanlı̆̆ Tebliğler Dergisi, 68, 482-632.

Nuhoğlu, H., (2008). İlköğretim fen ve teknoloji dersine yönelik bir tutum ölçeğinin geliştirilmesi, İlköğretim Online, 7, 627-639.

Şaşan, H. H., (2002). Yapılandırmacı öğrenme, Yaşadıkça Eğitim Dergisi, 74, 49-52.

Şeker, S., (2007). Yeni ilköğretim 6. sinıf fen ve teknoloji dersi öğretim programinın öğretmen görüşleri ışığında değerlendirilmesi (Gümüşhane İli Örneği), Karadeniz Teknik Üniversitesi Fen Bilimleri Enstitüsü, Yüksek Lisans Tezi, Trabzon.

Şimşek, N., (2004). Yapılandırmacı öğrenme ve öğretime eleştirel bir yaklaşım, Eğitim Bilimleri ve Uygulama, 3, 115-139. 
Tabachnick, B. G., \& Fidell, L. S., (2013). Using multivariate statistics, 6th ed. Boston : Pearson.

Taylor, P. C., Fraser, B., and White, L. R., (1994). CLES an instrument for monitoring the development of constructivist learning environment, Paper Presented at the Annual Meeting of the American Educational Research Association, New Orleans, April.

Tenenbaum, G., Naidu, S., Jegede, N., and Austin J., (2001). Constructivist pedagogy in conventional on-Campus and distance learning practice: An exploratory investigation, Learning and Instruction, 11, 87-111.

Tüysüz, C. ve Aydın, H., (2009). İlköğretim fen ve teknoloji dersi öğretmenlerinin yeni fen ve teknoloji programına yönelik görüşleri, Gazi Üniversitesi Gazi Eğitim Fakültesi Dergisi, 29, 37-54.

Özden, Y., (2006). 21. Yüzyılda Eğitimi Yeniden Canlandırma Çabaları, Türkiye'de eğitim bilimleri: Bir bilanço denemesi, (Ed: M. Hesapçıŏlu-A. Durmuş), Ankara: Nobel Yayın Dağıtım, s.: 504-522.

Özgür, B., (2008). Perceptions of 4th and 5th grade primary school students and their teachers about constructivist learning environments in science and technology courses, Ortadoğu Teknik Üniversitesi, Dokrota Tezi, Ankara.

URL, http://www.newyorkschools.com/articles/how-classroom-size-affects-learnings.html, 18 May1s, 2011.

Uzun, N. ve Keleş, Ö., (2010). Fen öğrenmeye yönelik motivasyonun bazı demografik özelliklere göre değerlendirilmesi, Gazi Üniversitesi Gazi Ĕ̈itim Fakültesi Dergisi, 30, 561-584.

Yapıcı, M. ve Leblebicier, N. H., (2007). Öğretmenlerin yeni ilköğretim programına ilişkin görüşleri”, İlköğretim Online, 6, 480-490.

Yılmaz Kaya, S., (2008). Fen öğretiminde yapılandırmacı yaklaşımın ilköğretim II. kademe ögrencilerinin başarıları üzerine etkisi, Selçuk Üniversitesi Fen Bilimleri Enstitüsü, Yüksek Lisans Tezi, Konya. 